\title{
PANDANGAN ESKATOLOGI INJIL MATIUS 27:51-54
}

\author{
Jack David Kawira \\ Sekolah Tinggi Teologi Reformed Injili Internasional, Jakarta
}

\begin{abstract}
ABSTRAK: Matius 27:51-54 memberitahukan kepada kita beberapa peristiwa luar biasa yang terjadi ketika Yesus mati di atas kayu salib. Beberapa teolog mengatakan bahwa kita tidak dapat melihat peristiwaperistiwa yang dicatat di dalam perikop tersebut benar-benar terjadi secara literal melainkan hanya sebagai konsep teologis yang dinyatakan di dalam peristiwa. Mereka mengatakan karena Matius sebenarnya telah dipengaruhi oleh budaya Helenistik yang kemudian menggunakan perangkat puisi Helenistik untuk menekankan bahwa Raja yang besar telah mati. Tetapi tentu saja pengertian semacam ini akan sangat menjadi ancaman bagi iman Kristen, khususnya mengenai kematian dan kebangkitan Tuhan Yesus Kristus sebagai peristiwa yang terjadi secara literal. Oleh karena itu, sangat penting bagi kita untuk mengerti bagian tersebut sebagai peristiwa yang terjadi secara literal. Kemudian kita akan melihat signifikansi kuasa kematian Tuhan Yesus Kristus yang bahkan memicu kebangkitan dari para orang kudus dan disisi lain bagian ini menjadi fitur baru yang dibawa oleh Matius ke dalam tradisi Sinoptik.
\end{abstract}

KATA KUNCI: Eskatologi, literal, puisi, helenistik, kebangkitan. 


\begin{abstract}
Matthew 27:51-54 tells us some extraordinary events that took place when Jesus died on the cross. Some theologians said we can not take this account as literal events but only as theological concepts which portrayed in the events. They claimed because Matthew was influenced by Hellenistic culture and use such Hellenistic poetic device which tried to emphasize that the great king has died. But of course, this kind of understanding will become a threat toward Christian faith, especially on the account of the death and the resurrection of Jesus Christ as literal events. Therefore it is very important for us to understand this account as literal event. Then we will see the significance of power in the death of Jesus Christ which triggers the resurrection of the saints and on the other hand, this part is the new feature of eschatology that Matthew brings to the synoptic tradition.
\end{abstract}

KEYWORDS: Eschatology, hellenistic, literal, poetic, resurrection.

\title{
Pendahuluan
}

Salah satu misteri terbesar dalam Alkitab muncul dalam Injil Matius 27:51-54, dimana pada perikop tersebut Matius memberitahukan suatu kejadian yang luar biasa besar mulai dari waktu Tuhan Yesus mati di atas kayu salib sampai pada saat kebangkitan-Nya. Kejadian yang luar biasa ini sebenarnya telah dimulai dari Matius 27:45, yaitu pada saat kegelapan menyelimuti seluruh wilayah tempat di mana Tuhan Yesus disalibkan, yang sudah tentu peristiwa ini akan mengingatkan kita pada nubuatan dari kitab Amos 8:9. Meskipun pada saat kematian Tuhan Yesus di atas kayu salib 
kegelapan menyelimuti seluruh wilayah itu, namun kematian Tuhan Yesus yang menebus dosa manusia membawa cahaya terang akan keselamatan bagi dunia yang sudah terhilang di dalam dosa, dan tentu saja hal tersebut hanya bagi mereka yang menerima-Nya dan memiliki iman yang menghidupkan atau yang sejati. ${ }^{1}$ Craig S. Keener juga mengatakan bahwa Matius 27:51-54 menunjukkan Allah Bapa membela ketidakbersalahan Kristus yang mati di atas kayu salib dengan tanda-tanda keajaiban di dalam alam, tanda yang hanya dapat dimengerti oleh prajurit-prajurit penyembah berhala yang mengeksekusi Tuhan Yesus. ${ }^{2}$ Paling tidak terdapat lima kejadian luar biasa yang dicatat pada perikop tersebut, seperti yang dapat kita lihat pada Matius 27:51-54 yang digaris bawahi di bawah ini.

${ }^{51}$ Lihatlah, tirai Bait Suci terkoyak menjadi dua dari atas sampai ke bawah.Terjadilah gempa bumi dan bukit-bukit batu terbelah. ${ }^{52}$ Kuburankuburan terbuka dan banyak orang kudus yang telah meninggal dibangkitkan. ${ }^{53}$ Sesudah kebangkitan Yesus, mereka keluar dari kubur, lalu masuk ke kota kudus dan menampakkan diri kepada banyak orang. ${ }^{54}$ Kepala pasukan dan prajurit-prajuritnya yang menjaga Yesus menjadi sangat takut ketika mereka melihat gempa bumi dan apa yang telah terjadi, lalu berkata, "Sungguh, Orang ini Anak Allah."

Sangat menarik bahwa bagian tersebut tidak terdapat paralelnya di dalam tiga Injil yang lain dan oleh sebab itu perikop tersebut dikategorikan sebagai salah satu hapax legomenon yang terdapat di dalam Injil Matius.

1 William Hendriksen, Exposition of the Gospel According to Matthew (Grand Rapids: Baker Academic, 1982), 974.

2 Craig S. Keener, Matthew (Downers Grove: IVP, 1997), Mt 27:45. Prajurit tersebut dikatakan dapat mengerti seluruh tanda-tanda keajaiban yang terjadi oleh karena konklusinya yang begitu mengagumkan di dalam Mat 27:54 dengan mengatakan "sungguh, Ia ini adalah Anak Allah." Bahkan di dalam Injil Matius peyamun-penyamun yang turut di salibkan dengan Tuhan Yesus dicatat turut mencela-Nya (Mat 27:44). 
Sehingga melalui bagian ini, kita dapat melihat keunikan penekanan yang ingin dinyatakan oleh Matius dibandingkan dengan tiga Injil yang lain. Namun, pada saat yang bersamaan bagian tersebut menjadi salah satu bagian yang paling sulit untuk dapat dimengerti. Paralel yang dicatat oleh Markus dan Lukas hanya bagian mengenai kegelapan yang menyelimuti semua wilayah dimana Tuhan Yesus disalibkan dan bagian mengenai tirai Bait Allah yang terbelah menjadi dua bagian (Mrk 15:33, 38 dan Luk 23:4445). Dan oleh karena itu, bagian ini tidak mempunyai bagian paralel yang lain di dalam Alkitab. Tentu saja begitu banyak pertanyaan, perdebatan dan pandangan yang telah muncul terkait dengan perikop tersebut. Namun, secara umum terdapat dua pandangan terhadap perikop tersebut yakni pandangan yang yakin bahwa semua peristiwa tersebut benar-benar terjadi secara literal dan sebagian lagi pandangan yang melihat semua peristiwa ini tidak benar-benar terjadi secara literal.

Di dalam makalah ini, pertama-tama kita akan melihat pertanyaanpertanyaan, semua perdebatan representatif yang terjadi dan isu-isu terkait yang telah muncul terhadap perikop tersebut. Kedua, kita akan melihat struktur, latar belakang beragam pandangan yang ada terkait perikop tersebut dan penjelasan secara eksegesis yang didasari oleh pandangan yang melihat bahwa semua hal tersebut terjadi secara literal beserta dengan perdebatan dan kesulitan-kesulitan yang ada, khususnya perbandingan perikop tersebut dengan surat I Korintus 15:20 dan Kolose 1:18. Terakhir, kita akan melihat suatu kesimpulan singkat untuk melihat signifikansi kuasa kematian Tuhan Yesus di atas kayu salib melalui semua peristiwa luar biasa yang terjadi pada saat kematian Tuhan Yesus, mulai dari terkoyaknya 
tirai Bait Allah hingga pemunculan orang-orang kudus di kota kudus ketika Tuhan Yesus bangkit.

\section{Pertanyaan, Perdebatan dan Isu-Isu dalam Matius 27:51-54}

Begitu banyak pertanyaan yang telah muncul terkait dengan perikop tersebut ketika kita menganggapnya terjadi secara literal, sebagai contoh: Apakah peristiwa gempa bumi dimaksudkan untuk menjelaskan bagaimana proses tirai dari Bait Allah terkoyak? Dan apakah tulisan Matius mengandung maksud bahwa kepala pasukan dan prajurit-prajurit yang lain melihat banyak kuburan terbuka dan orang-orang mati yang siap untuk menampakkan diri? Dan mengapa pula Matius mengatakan orang-orang yang bangkit tersebut menampakkan diri setelah kebangkitan Tuhan Yesus dua hari kemudian? Lalu apakah yang dilakukan oleh orang-orang kudus yang telah bangkit selama dua hari tersebut? Dan apakah yang terjadi dengan mereka yang bangkit pada waktu itu? Apakah mereka akan mati kembali ataukah hidup kekal selamanya? Semua pertanyaan ini bagi Tom Wright merupakan pertanyaan-pertanyaan yang salah untuk dipertanyakan. Dia juga menyimpulkan bahwa kejadian-kejadian yang dipaparkan oleh Matius 27:51-54 tidaklah memiliki paralel dengan sumber-sumber Kekristenan mula-mula dan juga tidak memiliki pengharapan-pengharapan dari masa intertestamental dan oleh karena itu, menurutnya kita dapat meragukan apakah cerita seperti ini dituliskan semata-mata hanya untuk menggenapkan nubuatan yang tidak pernah dimengerti oleh siapa pun sebelumnya. Oleh sebab itu, baginya beberapa cerita memang sangatlah janggal namun mungkin saja benar-benar terjadi secara literal, dan mungkin 
cerita ini menjadi salah satu bagian yang benar-benar terjadi, namun tentu saja di dalam terminologi sejarah tidaklah ada cara untuk membuktikannya. ${ }^{3}$

Beberapa teolog juga memiliki pandangan lain yang menilai bahwa kita tidaklah dapat menerima perikop tersebut secara literal, hal tersebut disebabkan oleh karena Matius kemungkinan besar telah dipengaruhi oleh budaya dan ide-ide Helenistik, dimana penggambaran kejadian-kejadian yang bersifat luar biasa pada saat kematian seorang besar termasuk terjadinya gempa bumi telah ada di dalam tulisan narasi The Georgics of Virgil di abad pertama sebelum masehi tentang kematian raja Julius Caesar, ${ }^{4}$ dan bahkan juga terjadi penampakan dari orang-orang yang telah mati pada tulisan Dio Cassius dalam sejarah Romawi. Dan oleh karena itu, Rudolf Schnackenburg menganggap bahwa tulisan-tulisan di dalam Matius 27:51-54 hanyalah sebuah konsep-konsep teologi yang di proyeksikan di dalam sebuah kejadian, dan dia juga percaya dengan pasti bahwa Matius tentu telah dipengaruhi oleh budaya dan pemikiran dari Helenistik. Namun, menurutnya Matius melihat semua tulisan ini sebenarnya menunjuk kepada kebangkitan Yesus, yang dinyatakan dalam peristiwa kematian Tuhan Yesus. ${ }^{5}$ Di sisi yang lain, John Dominic Crossan memahami perikop tersebut sebagai bentuk penulisan yang bersifat metafora dan puisi, bahkan kebangkitan Tuhan Yesus sekalipun. Dia mengakui yang mempengaruhi kesimpulan tersebut adalah harrowing of hell theology yang dapat ditemukan

3 N.T. Wright, Christian Origins and the Question of God, 1st North American ed. (Minneapolis: Fortress Press, 1992), 633, 636.

4 Arthur S. Way, The Georgic of Virgil (London, New York: Macmillan, 1912), I. 475.

5 Rudolf Schnackenburg, The Gospel of Matthew (Grand Rapids: Eerdmans, 2002), 290. 
dalam Odes of Solomon 42:10-20, Injil Petrus 10.39-42, dan 1 Petrus 3:18-19; 4: 6. ${ }^{6}$ Oleh sebab itu, Crossan juga setuju terhadap pandangan dari pemikiran Rudolf Schnackenburg mengenai perikop tersebut, dimana ia melihat bagian ini hanya sebagai perangkat puisi yang sedang ingin memberikan penekanan khusus bahwa seorang raja yang sangat besar telah meninggal. ${ }^{7}$

\section{Struktur, Latar Belakang dan Penjelasan Secara Eksegesis Dalam Matius 27:51-54}

Struktur Matius 27:51-54

Perikop tersebut sebenarnya ditulis dengan teknik penulisan yang sangat menarik, yang membedakan perikop tersebut dengan keseluruhan bagian narasi kesengsaraan Tuhan Yesus dari Matius 27:45-54. Perikop tersebut membuat makna eskatologi dari penyaliban Tuhan Yesus menjadi begitu nyata, dan yang menuntun para pembaca menuju kepada klimaks di dalam ayat 54. Selain itu Matius dalam menuliskan perikop tersebut juga menggunakan fitur parataxis, divine passives dan extensive parallelism. ${ }^{8}$

\footnotetext{
6 Michael R. Licona, The Resurrection of Jesus: A New Historiographical Approach (Downers Grove: IVP, 2010), 527-530.

7 Ibid., 552.

8 W.D. Davies dan Dale C. Allison Jr, A Critical and Exegetical Commentary On the Gospel According to Saint Matthew (New York: T\&T Clark, 2004), 628.
} 
Adapun hal tersebut dapat kita lihat di bawah ini di dalam bahasa aslinya:

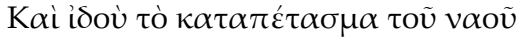

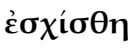

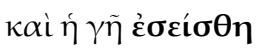

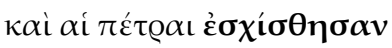
$\kappa \alpha \grave{i} \tau \dot{\alpha} \mu \nu \eta \mu \varepsilon \tilde{\imath} \alpha \dot{\alpha} v \varepsilon \hat{\omega} \chi \theta \eta \sigma \alpha v$
$\kappa \alpha i ̀ ~ \tau o \lambda \lambda \dot{\alpha} \sigma \omega \dot{\omega} \alpha \tau \alpha \tau \tilde{\omega} \nu \kappa \varepsilon \kappa o u \eta \eta \mu \dot{v} \nu \omega \nu$

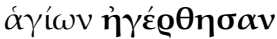

\author{
(Dan lihatlah! Tabir Bait Suci \\ terkoyak) \\ (Dan terjadilah gempa bumi) \\ (Dan bukit-bukit batu terbelah) \\ (Dan kuburan-kuburan terbuka) \\ (Dan banyak orang kudus yang \\ telah meninggal dibangkitkan)
}

Jikalau kita perhatikan semua kata kerja yang dicetak tebal di dalam peristiwa tersebut, maka kita dapat melihat dengan jelas bahwa semua kata kerja menggunakan aorist pasif indikatif, di mana hal tersebut merupakan suatu tanda yang jelas bahwa Tuhan yang sedang bekerja dan melakukan semua peristiwa tersebut dan bukan hanya itu saja, penggunaan aorist tense di dalam bagian ini juga menyatakan bahwa kejadian ini merupakan kejadian yang tidak akan terulang kembali. ${ }^{9}$ Demikian pula pandangan dari Donald Hagner di dalam tulisannya yang bahkan memberikan judul pada bagian ini sebagai kejadian-kejadian spektakuler yang mengikuti peristiwa kematian Yesus dan dijelaskan di dalam lima penggunaan berurutan dari kata kerja tersebut dimana menyatakan bahwa Tuhanlah yang menjadi subyek yang melakukan tindakan tersebut. ${ }^{10}$

\footnotetext{
9 William D. Mounce, Basics of Biblical Greek Grammar, 2nd ed. (Grand Rapids: Zondervan, 2003), 202, 212.

10 Donald A. Hagner, Word Biblical Commentary, vol. 33b, Matthew 14-28 (Phillidelphia: Thomas Nelson, 1995), 846-48.
} 
Di dalam struktur perikop tersebut, kita juga dapat melihat adanya struktur paralelisme yang sangat teratur seperti yang dapat kita lihat dalam struktur di bawah ini: ${ }^{11}$

\section{43-54 ( $\mathrm{J}^{3}$, p. 1377). THE THREE HOURS' DARKNESS. $\mathrm{J}^{3}|\mathrm{~K}| 1 \mid \mathrm{45}$. Sign in heaven. Darkness. m | 46. Cry. "Eli, Eli". L | 47-49. Misunderstanding of Bystanders. $K|m|$ so. Cry. Reperted. $l \mid s 1-53$. Signs on earth. Veil, earthquake, \&c. $L$ | 54. Understanding of Centurion and others.}

Selain itu kita juga dapat melihat pengulangan kosa kata dan permainan kata seperti: kata bumi yang terdapat di dalam ayat $45 \gamma \tilde{\eta} v$ dan $51 \gamma \tilde{\eta}$, kata terkoyak atau terbelah di dalam ayat 51a $\dot{\varepsilon} \sigma \chi i ́ \sigma \theta \eta$ dan 51c

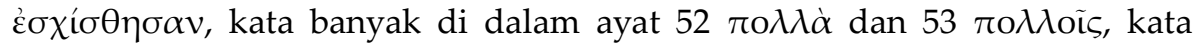

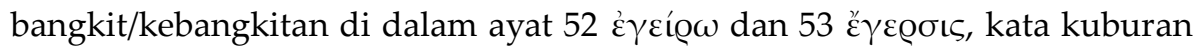

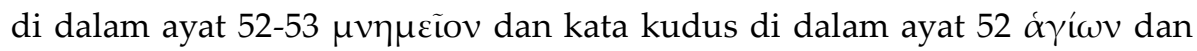
$53 \alpha$ óíav. Semua permainan kata tersebut kemudian akan mengingatkan kita mengenai peristiwa paskah di dalam Matius 28:1-10, yang bukan hanya mengulang kata bangkit tetapi juga gempa, kuburan dan akar kata takut $\phi о \beta$-di dalam ayat 54 dan Mat 28:10. ${ }^{12}$ Sehingga melalui analisis ini kita dapat melihat relasi yang begitu erat antara mujizat yang terjadi di dalam peristiwa kematian dan kebangkitan Tuhan Yesus, yang sama-sama menggunakan penulisan dengan fitur divine passives dan extensive parallelism. Dan oleh karena itu, bila salah satu bagian dikatakan tidak terjadi secara

11 E. W. Bullinger, Companion Bible: King James Version, Burgundy, Bonded Leather, Burgundy Bonded Leather ed. (Grand Rapids: Kregel Publications, 1990), 1378.

12 Ulrich Luz dan H. Koester, Matthew 21-28: A commentary. (Minneapolis: Fortress Press, 2005), 560. 
literal maka bagian yang lain juga dapat dianggap tidak terjadi secara literal dan sebaliknya.

\section{Latar Belakang}

Tidak dapat dipungkiri bahwa Matius 27:51-54 merupakan bagian yang paling janggal dan "aneh" di dalam Alkitab, namun tidak berarti pernyataan dari Rudolf Schnackenburg bahwa Matius dipengaruhi oleh budaya dan pemikiran Helenistik itu menjadi benar. Hal ini disebabkan oleh karena latar belakang dari perikop tersebut berakar dengan sangat kuat dari kepercayaan iman di dalam Perjanjian Lama akan adanya kebangkitan secara menyeluruh bagi umat Allah ketika Mesias datang (Dan 12:2; Yeh 37:12). ${ }^{13}$ Bahkan beberapa teolog percaya bahwa bagian ini merupakan realisasi dari nubuatan nabi Zakharia (Za 14:4-5), dimana di dalam perikop tersebut terdapat (i) kebangkitan dari orang mati yang mengambil tempat di luar Yerusalem dan hal ini menjadi kontras dalam kitab Yehezkiel 37, dimana kebangkitan terjadi di dalam diaspora; (ii) terjadinya gempa bumi; (iii) kata $\sigma \chi i \zeta \omega$ yang digunakan dalam bentuk pasif, dan di dalam hubungannya dengan gunung (Zakharia) dan bukit batu (Matius); dan (iv) orang-orang yang dibangkitkan disebut sebagai orang-orang kudus atau $\alpha$ í

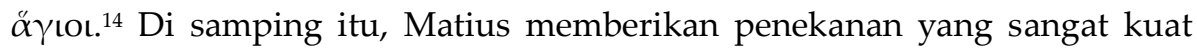
pada Tuhan Yesus Kristus sebagai penggenapan dari nubuatan Perjanjian lama.Salah satu alasannya adalah karena Matius memiliki fokus pada

13 D. A. Carson and G. K. Beale, eds., Commentary on the New Testament Use of the Old Testament (Nottingham: Baker Academic, 2007), 442.

14 Davies and Allison, A Critical and Exegetical Commentary, 629. 
pendengar Yahudi Kristen, meskipun memang Injil Matius tetap memiliki aspek universalitasnya.

Merupakan hal yang sangat penting bagi kita untuk memahami bahwa Matius tidaklah dipengaruhi oleh pemikiran Helenistik ketika ia menuliskan perikop tersebut seperti tudingan dari Rudolf Schnackenburg dan John Dominic Crossan. Hal ini disebabkan Matius menujukan Injilnya kepada orang-orang Yahudi Kristen, yang tentu saja memiliki latar belakang dan perhatian kepada Yudaisme. Selain itu penulisan Injil Matius juga bertujuan untuk memberitakan injil kepada orang-orang Yahudi yang memiliki latar belakang Perjanjian Lama yang kuat. Hal ini dibuktikan dengan adanya penekanan Matius kepada banyaknya penggenapan nubuat para nabi di dalam Injil Matius. Meskipun disisi lain, memang benar bahwa Matius juga memiliki perhatian untuk menjangkau orang-orang nonYahudi. Hal ini dapat terlihat dari masuknya orang-orang non-Yahudi di dalam silsilah Tuhan Yesus di dalam Matius 1, dan yang kemudian juga dinyatakan di dalam Matius 28:19-20 mengenai mandat pemberitaan Injil yang menjangkau sampai kepada bangsa-bangsa lain. Namun hal ini tidaklah membuat argumentasi dari Rudolf Schnackenburg dan Crossan menjadi benar karena menurut Michael R. Licona, Matius jika hanya ingin memberikan penekanan bahwa raja besar telah meninggal ia cukup hanya memberikan argumentasi sederhana dengan memproklamasikan bahwa hari TUHAN telah datang kepada orang-orang yang memiliki latar belakang pemikiran Yahudi di dalam benak mereka. ${ }^{15}$ Dan kemudian apa yang dipikirkan oleh Crossan tentang harrowing of the hell theology tentulah tidak

15 Licona, Resurrection of Jesus, 552. 
benar, karena tanggal penulisan dari Odes of Solomon berkisar antara akhir abad pertama hingga awal abad ke dua, dan sumber dari Injil Petrus juga perlu dipertanyakan. Oleh karena itu, para sejarahwan yang terkemuka seharusnya tidak perlu menaruh bobot yang besar di dalam mendukung bahwa harrowing of hell adalah kepercayaan dari jemaat mula-mula, sehingga membuatnya berada di dalam persaingan dengan kebangkitan tubuh dari Tuhan Yesus Kristus. ${ }^{16}$

Menurut Michael R. Licona, jika beberapa atau semua kejadian spektakuler yang dipaparkan ketika Tuhan Yesus mati hanyalah dipandang sebagai penekanan yang bersifat puisi, maka kita juga dapat bertanya, apakah kemudian kebangkitan Kristus dapat dipandang dengan cara yang serupa pula? Namun paling tidak terdapat dua bentuk pengamatan yang terbukti sangat menolong di dalam memberikan jawaban terkait masalah tersebut. Pertama, sama sekali tidak terdapat indikasi bahwa jemaat Kristen mula-mula memahami atau menafsirkan kebangkitan Kristus sebagai bentuk metafora atau pun di dalam bentuk puisi dan yang menolak kebangkitan literal yang terjadi atas tubuh-Nya. Sebaliknya kebangkitan tubuh Kristus secara literal merupakan penafsiran yang di intensikan oleh Matius terlihat sangat jelas. Kedua, jikalau benar kebangkitan Kristus adalah dimaksudkan secara metafora atau puisi maka sangatlah aneh bila tidak ada satu pun dari musuh-musuh Tuhan Yesus yang mengkritik bahwa kejadian ini hanyalah konsep teologis yang dipaparkan di dalam bentuk kejadian atau puisi, dan dengan demikian menjadikan musuh-musuh Tuhan Yesus tersebut salah paham akan perangkat puisi yang dimengerti sebagai

16 Ibid., 546-547. 
kejadian literal. Hal ini dapat dengan jelas kita lihat dimana musuh-musuh Tuhan Yesus mengajukan teori bahwa Yesus selamat dari kematian, tubuhNya dicuri, para saksi mata yang tidak dapat dipercaya bahkan keberadaan murid-murid Tuhan Yesus yang berhalusinasi. ${ }^{17}$

Setelah melihat beberapa argumentasi yang mencoba membela keliteralan dari perikop yang kita bahas tersebut maka kita dapat menyimpulkan bahwa: Pertama, Matius tidaklah dipengaruhi oleh pandangan Helenistik dan justru sebaliknya Matius dipengaruhi kuat oleh Perjanjian Lama. Kedua, kepercayaan tentang harrowing of the hell theology tidak dapat dibuktikan telah memengaruhi jemaat mula-mula dan oleh karena itu, kepercayaan ini tidaklah memengaruhi Matius ketika menuliskan perikop tersebut. Ketiga, dengan melihat literalnya kebangkitan Tuhan Yesus maka kita dapat yakin bahwa semua kejadian yang terjadi di dalam Matius 27:51-54 adalah peristiwa yang benar-benar terjadi secara literal, apalagi dengan analisis keeratan antara Matius 27:51-54 dengan Matius 28:1-10, seperti yang telah dibahas sebelumnya.

\section{Penjelasan Secara Eksegesis Dalam Matius 27:51-54}

Berdasarkan apa yang telah kita bahas, maka pengertian bahwa semua kejadian-kejadian pada saat kematian Tuhan Yesus adalah sungguhsungguh terjadi secara literal merupakan hal yang sangat penting, karena ketika kita berpikir bahwa perikop tersebut ditulis secara puisi atau tidak literal maka kita dapat pula menolak bahwa kebangkitan Tuhan Yesus

\footnotetext{
17 Ibid., 553.
} 
Kristus terjadi secara literal, yang mana diyakini oleh umat Kristen mulamula hingga saat ini. Dan oleh sebab itu kita dapat melihat bahwa semua peristiwa yang terjadi ketika Tuhan Yesus mati adalah peristiwa yang benarbenar terjadi secara literal, bahkan kebangkitan orang-orang kudus yang telah mati juga terjadi secara literal. Untuk itu, kita akan membahas dengan lebih terperinci Matius 27:51-54 dengan pendekatan eksegesis, didukung oleh analisis cara penulisan yang telah kita lakukan sebelumnya.

27:51 Matius mulai memperkenalkan peristiwa-peristiwa luar biasa yang terjadi secara berurutan dengan memberikan suatu penekanan menggunakan Kaì i̇où (Dan Lihatlah), yang akan membuat para pembaca lebih memberikan perhatiannya pada perikop tersebut. Dan di dalam ayat 51 ini, terdapat tiga kejadian yang dicatat oleh matius, yakni: tirai Bait Allah terkoyak, gempa bumi dan bukit-bukit batu terbelah, kata terkoyak dan terbelah menggunakan kata dasar yang sama $\sigma \chi \mathbf{i} \zeta \boldsymbol{\omega} \omega$ dimana hal ini menunjukan adanya permainan pengulangan kata oleh Matius. Selain itu seperti yang sudah disebutkan sebelumnya ketiga kejadian ini sama-sama menggunakan bentuk aorist pasif indikatif yang mana Tuhan dimengerti sebagai subjek yang menyebabkan tirai tersebut terkoyak, gempa bumi dan terbelahnya bukit-bukit batu.Sehingga kita tidak dapat mengatakan tirai yang terkoyak dan bukit-bukit batu yang terbelah memiliki hubungan sebab akibat dengan terjadinya gempa, meskipun secara logis hal tersebut dapat diterima. Namun, yang sebenarnya menjadi penekanan dari Matius adalah bahwa Tuhan yang menyebabkan ketiga kejadian tersebut terjadi, sehingga peristiwa tersebut bukanlah suatu kebetulan dari bencana alam, melainkan pertunjukan kuasa sekaligus murka Allah. 
Memang tidak dapat dipungkiri bahwa beberapa teolog melihat peristiwa tirai Bait Allah yang terkoyak dan bukit-bukit batu terbelah adalah sebab dari gempa bumi. Tetapi John Nolland memiliki argumentasi yang menarik untuk menolak pandangan tersebut. Ia melihat bahwa di dalam kitab perjanjian lama gempa bumi dan terbelahnya bukit-bukit batu adalah suatu ekspresi yang lumrah mengenai penggambaran ketakutan akan hari penghukuman Tuhan yang akan datang seperti yang dinyatakan di dalam 2 Samuel 22:7-8 dan Nahum 1:6. Namun, perikop di dalam Matius 27:51-54 ini ingin menyatakan lebih jauh afirmasi dari murka Allah atas apa yang dilakukan kepada Kristus. ${ }^{18}$ Sehingga murka Tuhan yang dinyatakan, bukan hanya gempa bumi dan terbelahnya bukit-bukit batu tetapi memuncak hingga terkoyaknya tirai Bait Allah menjadi dua.Dan hal inilah yang menjadi penekanan yang dimaksudkan oleh Matius, bukannya hubungan kausalitas kejadian peristiwa.

Selain dari pada itu, banyak teolog juga berdebat mengenai signifikansi tirai Bait Allah, apakah tirai di sebelah dalam yang menutupi ruangan Maha Kudus ataukah tirai di sebelah luar yang memisahkan tempat kudus dengan pekarangan. Di dalam makalah ini kita akan mencoba untuk melihat signifikansi dari dua pandangan tersebut daripada memilih salah satu dari keduanya yang tentunya akan menghantar kita melihat signifikansi kuasa kematian Kristus.

Di dalam LXX kata $\kappa \alpha \tau \alpha \pi \varepsilon ́ \tau \alpha \sigma \mu \alpha$ (tirai) dapat berarti kedua-duanya, baik bagi tirai di bagian dalam maupun bagi tirai di bagian luar. Beberapa

18 John Nolland, The Gospel of Matthew: A Commentary On the Greek Text, The New International Greek Testament Commentary (Grand Rapids: Eerdmans, 2005), 1213. 
teolog yang berpandangan bahwa yang dimaksud adalah tirai bagian sebelah luar melihat bahwa terkoyaknya tirai tersebut sebenarnya merupakan bentuk simbolik atau nubuatan akan kehancuran Bait Allah di tahun $70 \mathrm{M}$. Penafsiran yang menarik ini secara khusus mirip dengan peringatan yang dinyatakan tentang penghakiman terhadap Bait Allah yang tidak dapat dihindari seperti yang dicatat baik oleh Joshepus maupun di dalam Talmud. Dan peristiwa tersebut menginagurasikan akhir dari Bait Allah, yang pada saat bersamaan membenarkan atau membela nubuatan Tuhan Yesus mengenai keruntuhan Bait Allah tersebut. Lebih lanjut, memang sudah sewajarnya, jika setelah orang-orang mengejek TuhanYesus akan nubuatan-Nya mengenai Bait Allah di dalam Matius 27:40, perkataanNya haruslah di benarkan. ${ }^{19}$ Craig L. Blomberg juga memiliki pendapat yang sama, dimana ia berpikir bahwa tirai yang terkoyak sangatlah mungkin tirai yang memisahkan tempat bagi orang-orang Yahudi dengan tempat bagi orang-orang bukan Yahudi, tetapi ia juga tetap terbuka bagi alternatif lain. Oleh sebab itu di dalam mendukung pandangannya, ia berargumentasi bahwa di dalam Efesus 2:14 terlihat seperti sedang mengingat kembali peristiwa terkoyaknya tirai Bait Allah ketika berbicara tentang merubuhkan tembok pemisah antara orang-orang Yahudi dengan orang-orang bukan Yahudi di dalam Kristus. ${ }^{20}$ Dan bahkan menurut John Nolland, dari situs tradisional bukit Golgota atau tempat dimana Tuhan Yesus disalib kita dapat melihat tirai yang ada di bagian sebelah luar Bait Allah. Dan jika Tuhan digambarkan sedang meninggalkan Bait Allah maka tentulah Ia

19 Davies dan Allison, A Critical and Exegetical Commentary, 629.

20 Craig L. Blomberg, Matthew (Nashville: Holman Reference, 1992), 420. 
harus melewati dua tirai tersebut, namun jika hanya satu saja yang disebutkan, maka lebih mungkin tirai yang berada di sebelah luar, seperti halnya dengan gempa bumi dan terbelahnya bukit-bukit batu menjadi tanda "pernyataan Allah" yang dapat dilihat oleh publik, sehingga tirai sebelah luarlah yang sangat mungkin untuk dimaksudkan oleh Matius. ${ }^{21}$

Dan disisi lain, melalui dasar dari surat Ibrani 6:19; 9:3 dan 10:20 maka hal yang lumrah bagi kita untuk melihat bahwa tirai yang terkoyak adalah tirai di bagian sebelah dalam atau "tirai yang kedua", tirai yang memisahkan ruangan Kudus dengan ruangan Maha Kudus. Dan pada saat kematian Tuhan Yesus tirai tersebut tiba-tiba terkoyak menjadi dua bagian dari atas sampai ke bawah, dan peristiwa tersebut terjadi tepat pada jam tiga sore dimana para imam seharusnya sedang sibuk-sibuknya di dalam Bait Allah, dan mempersembahkan korban penghapus dosa. Oleh karena itu, terkoyaknya tirai sebelah dalam tersebut memberikan simbolisme yang signifikan berdasarkan dua pertimbangan: Pertama, kejadian tersebut terjadi tepat pada waktu Kristus mati; dan yang kedua, hal tersebut dijelaskan di dalam Ibrani 10:19-20 bahwa melalui kematian Tuhan Yesus Kristus, disimboliskan dengan terkoyaknya tirai menjadi dua, menjadi jalan bagi kita untuk masuk ke ruangan Maha Kudus tempat kediaman dimana Allah berada yang terbuka bagi siapa saja yang berlindung kepada-Nya seperti apa yang dinyatakan dengan begitu jelas dalam Surat Ibrani 4:16.22

Dengan melihat kedua pandangan tersebut, kita justru dapat melihat signifikansi kematian Tuhan Yesus di atas kayu salib dengan lebih

\footnotetext{
21 Nolland, Gospel of Matthew, 1213.

22 Hendriksen, Exposition of the Gospel According to Matthew, 974.
} 
komprehensif. Dimana kematian Tuhan Yesus bukan hanya menjadi perantara yang membawa kita untuk dapat langsung berhubungan dengan Allah Bapa tetapi juga kematian yang menghancurkan tembok pemisah antara orang Yahudi dengan orang bukan Yahudi.Oleh karena itu, kematian Kristus membawa pendamaian bukan hanya terhadap Tuhan tetapi juga terhadap sesama manusia.

27:52-53 Di dalam bagian ini Matius melanjutkan kejadian-kejadian yang luar biasa yang terjadi ketika Tuhan Yesus mati. Kuburan-kuburan terbuka dan banyak orang kudus yang telah meninggal bangkit dan keluar dari kubur setelah kebangkitan Tuhan Yesus dan menampakkan diri kepada banyak orang di dalam kota kudus. Sangat sulit memang untuk mengerti apa yang sebenarnya tengah terjadi pada saat itu, namun sangatlah penting bagi kita untuk mengerti bagian tersebut sebagai kejadian yang sungguhsungguh terjadi secara literal karena bagian ini memberikan penekanan kepada kuasa kematian Tuhan Yesus Kristus. G.K Beale mengatakan bagian tersebut adalah gambaran akan kebangkitan dari orang-orang percaya yang telah mati di masa yang akan datang. ${ }^{23}$ Matius juga memberitahukan pembacanya pengharapan eskatologi tentang keselamatan, dimana kematian Tuhan Yesuslah yang justru memicu kebangkitan orang-orang kudus di dalam peristiwa tersebut, sehingga hal ini menjadi fitur baru yang di bawa oleh Matius di dalam tradisi Injil sinoptik. ${ }^{24}$

\footnotetext{
23 Carson dan Beale, Commentary on the New Testament Use of the Old Testament, 442.

24 L. Morris, The Gospel according to Matthew (Grand Rapids; Leicester: Eerdmans; IVP, 1992), 725 .
} 
John Calvin bahkan mengatakan kebesaran dan energi Ilahi dari kematian Kristus berpenetrasi bahkan sampai ke dalam dunia orang mati.Hal ini disebakan kematian-Nya merupakan sumber dan awal dari kehidupan baru. Calvin percaya bahwa orang-orang kudus tersebut menerima kehidupan ketika Tuhan Yesus bangkit karena dikatakan di dalam Kolose 1:18 bahwa Kristus adalah "first born from the dead", dan di dalam 1 Korintus 15:20 dikatakan Kristus "first fruits of those who rise", sehingga dengan kematian-Nya Ia memulai dan melalui kebangkitan-Nya Ia menyelesaikannya. ${ }^{25}$

Di sisi yang lain, Craig L. Blomberg memegang pandangan yang sangat kuat bahwa orang-orang kudus tersebut bangkit pada hari dimana Tuhan Yesus mati. Dia berargumen, jika memang benar bahwa orang-orang kudus tersebut bangkit ketika Tuhan Yesus bangkit maka peristiwa ini merupakan satu-satunya peristiwa yang ditunda sampai (atau setelah) kebangkitan Tuhan Yesus. Namun, bila kita melihat perikop tersebut maka semua peristiwa yang terdapat di di dalam bagian ini dimaksudkan terjadi pada saat atau dekat dengan saat kematian Tuhan Yesus. Menurutnya, surat 1 Korintus 15:20 tidak memberikan suatu dasar yang cukup kuat untuk menolak pandangan bahwa orang-orang kudus tersebut bangkit sebelum Kristus bangkit, karena kuasa kematian dan kebangkitan dari Tuhan Yesus Kristuslah yang menjadi dasar sangat kuat bahkan bagi orang-orang kudus tersebut untuk mengalami kebangkitan yang penuh kemuliaan. Disamping itu, surat I Korintus 15:20 memberikan perbandingan antara kebangkitan Kristus dengan keadaan di masa yang akan datang ketika Kristus datang

25 John Calvin, Calvin's Commentaries, 23 Vol., 500ed (Grand Rapids: Baker, 2009), 324-325. 
kedua kali yang kemudian akan membangkitkan semua orang percaya, dan oleh karena itu Kristus adalah first fruit atau yang pertama bangkit dari antara orang mati. ${ }^{26}$ Dan tanda ini, seperti halnya dengan yang dinyatakan di dalam ayat 51 dan 52a memiliki sifat nubuatan, dimana menyatakan bahwa kematian Tuhan Yesus Kristus memberikan suatu jaminan dari kebangkitan yang penuh kemuliaan pada saat Kristus datang kali yang ke dua.

Banyak teolog yang sependapat bahwa orang-orang kudus yang dibangkitkan adalah orang-orang Yahudi yang dibenarkan sebelum jaman Tuhan Yesus, mungkin mereka adalah bapa-bapa patriakal, para nabi, ataupun para martir. ${ }^{27}$ Kenneth L. Walters menjelaskan bahwa terdapat perbedaan antara kebangkitan yang dikenal dengan istilah resuscitation dengan resurrection. Dimana pada resuscitation orang yang dibangkitkan akan mati kembali seperti halnya yang terjadi dengan kebangkitan Lazarus. Tetapi lain halnya dengan resurrection dimana orang yang dibangkitkan tidak akan mati kembali. Dan menurutnya, orang-orang kudus yang bangkit tidaklah mati kembali, karena pertama peristiwa ini merupakan kebangkitan yang bersifat masal bagi orang-orang kudus yang digambarkan tengah tertidur dan kedua, peristiwa ini dilakukan tanpa adanya campur tangan manusia atau pihak ketiga, hanya Tuhan dengan orang yang mati. Lain halnya pada peristiwa resuscitation terdapat tiga pihak yakni, Tuhan, orang yang mati dan manusia yang lain yang Tuhan pakai untuk membangkitkan

\footnotetext{
26 Hendriksen, Exposition of the Gospel According to Matthew, 975.

27 Donald A. Hagner, Word Biblical Commentary, 849
} 
orang yang telah mati. ${ }^{28}$ Dan oleh karena itu, pengertian bahwa orang yang bangkit tersebut akan mengalami kematian lagi tidaklah dapat dibenarkan.

Sesudah kebangkitan Tuhan Yesus, orang-orang kudus ini masuk kedalam kota kudus - Yerusalem dan menampakkan diri kepada banyak

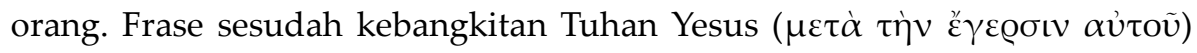
menjadi bagian hangat di dalam perdebatan teologis. Paling sedikit terdapat tiga pandangan mengenai bagian ini: (1) sebagai potongan yang tertinggal dari pre-Matthean Easter tradition. Secara sederhana bagian ini mengatakan bahwa Matius ingin membawa tradisi old Easter kepada peristiwa penyaliban, tetapi kemudian ia meninggalkan frase tersebut dan berhenti bahkan melupakan tujuannya sendiri(2) Merupakan bagian tambahan dari redaksional Matius. Hal tersebut memiliki sedikit dukungan dengan

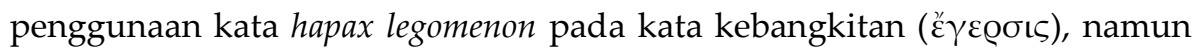
tidak pada kata setelah ( $\mu \varepsilon \tau \dot{\alpha})$. Dan dalam ayat 52 telah dikatakan terlebih dahulu bahwa orang-orang kudus bangkit, dan di ayat 54 dikatakan setelah mereka melihat apa yang telah terjadi. Oleh karena itu, kita justru dapat melihat kejadian di dalam ayat 53 termasuk di dalamnya dan dengan demikian menjadikan argumentasi ini juga tidak mungkin benar (3) sebagai poss-Matthean gloss. Dimana para teolog berargumentasi bahwa oleh karena tradisi Yesus adalah yang pertama bangkit (first fruit) maka bagian ini di tambahkan di dalam perikop ini. Tetapi argumentasi tersebut juga bermasalah karena akan membuat yang menambahkan bagian tersebut sangat ceroboh dengan meletakkannya setelah ayat 52. Selain itu, bukti

28 Kenneth L.Walters, “Matthew 27:52-53 as apocalyptic apostrophe: Temporal-Spatial Collapse in The Gospel of Matthew," Journal of Biblical Literature 122/3(2003): 489-515. 
tekstual dari frase tersebut juga cukup kuat mendukung keabsahannya. ${ }^{29}$ Sehingga, semua argumentasi yang ada yang meragukan frase "sesudah kebangkitan Tuhan Yesus" tidaklah kuat. Dan itu berarti bahwa kita harus menerima frase tersebut sebagai tulisan asli dari Matius.

Disisi lain, dengan melihat bagian ini secara lebih terperinci Matius dengan sangat jelas menunjukkan bahwa terdapat dua peristiwa gempa bumi, yaitu pada saat kematian Tuhan Yesus (Mat 27:51-52) dan pada saat kebangkitan-Nya (Mat 28:2). Memang menjadi sangat mudah untuk dijelaskan bila hanya terjadi satu gempa bumi, karena hal tersebut berarti kebangkitan orang-orang kudus bertepatan dengan kebangkitan Tuhan Yesus. Namun, hal yang sebaliknyalah yang terjadi, sehingga dengan tidak dapat terbantahkan kebangkitan orang-orang kudus terjadi sebelum Kristus bangkit. Hal inilah yang kemudian membuat Gundry berspekulasi dengan mengatakan bahwa orang-orang kudus yang telah dibangkitkan menanti kebangkitan Kristus selama tiga hari di dalam kuburan. ${ }^{30}$

Kemudian menjadi hal sangat menarik bahwa Matius menyebutkan Yerusalem sebagai kota kudus dan orang-orang Yahudi sebagai orang kudus setelah penghakiman yang dinyatakan oleh Tuhan Yesus atas Israel di dalam Matius pasal 23 dan 24. Dan hal ini sebenarnya memberikan kepada kita suatu isyarat bahwa orang-orang benar yang tersisa di Israel akan tetap dijaga oleh Tuhan. ${ }^{31}$ Sedangkan di sisi lain, pembaca dari Injil Matius mengetahui bahwa Yerusalem yang adalah tempat dimana para Nabi dan

29 Luz dan Koester, Matthew 21-28: A commentary, 569.

30 Donald A. Hagner, Word Biblical Commentary, 850.

31 Blomberg, Matthew, 421. 
para wakil Tuhan dibunuh akan segera menerima penghakiman dari Tuhan, karena kota kudus tersebut merupakan tempat dimana orang banyak berteriak bahwa mereka dan anak-anak mereka akan menanggung darah dari Tuhan Yesus (Mat 27:25). Dan ketika orang-orang kudus yang telah meninggal menampakkan diri di Yerusalem dan menampakkan diri ke banyak orang menjadi suatu tanda penghakiman Tuhan yang akan segera tiba, dan konfirmasi penghukuman kepada orang-orang yang ada di Yerusalem. ${ }^{32}$ Oleh karena itu, kita dapat melihat dua implikasi dari peristiwa tersebut, yaitu Tuhan tetap memperhatikan orang-orang benar yang tersisa di Yerusalem dan pernyataan kepastian penghukuman bagi orang Yerusalem lainnya.

27:54 Bagian terakhir di dalam perikop ini diakhiri dengan pengakuan yang sangat dramatis oleh kepala pasukan dan prajurit-prajurit yang bersama dengannya. Melalui ayat ini kita dapat melihat bagaimana Matius menyimpulkan semua yang terjadi dan efek dari kematian Tuhan Yesus Kristus "ketika kepala pasukan dan mereka yang bersama dengannya, melihat Yesus yang tersalib, gempa bumi dan semua yang telah terjadi, maka mereka kemudian menjadi takut, dan mengatakan Sungguh, Ia ini adalah Anak Allah." Pengakuan ini memiliki arti yang sangat khusus pada kemurnian pertobatan oleh karena di dalam ayat 33-36 mereka memperolokolok Tuhan Yesus dan kemudian di dalam ayat 54 ini mereka menyatakan suatu pengakuan yang tulus. ${ }^{33}$ Dan oleh karena itu, kita dapat melihat suatu

32 Ulrich Luz dan H. Koester, Matthew 21-28: A commentary. (Minneapolis: Fortress Press, 2005), 567.

33 Davies dan Allison, A Critical and Exegetical Commentary, 635. 
isyarat yang dinyatakan oleh Matius bahwa keselamatan juga dibukakan kepada orang-orang bukan Yahudi.

Kepala pasukan dan prajurit-prajurit yang bersama dengannya tidak hanya menyaksikan peristiwa yang luar biasa ini mulai dari kegelapan sampai kepada peristiwa dimana Tuhan Yesus mati, yang membuat mereka merasakan ketakutan yang luar biasa. Tetapi mereka yang menjaga Tuhan Yesus di atas bukit Golgota tentu juga sudah melihat dan mendengar bagaimana Tuhan Yesus diolok-olok dan dipermainkan oleh pemimpinpemimpin agama Yahudi akan ucapan Tuhan Yesus yang menyatakan bahwa diri-Nya adalah Anak Allah. Dan sangat mungkin sekali kepala pasukan mengkombinasikan semua impresi yang di dapatnya dan kemudian menyimpulkan dengan mengatakan "Sungguh, Ia ini adalah Anak Allah!" Legenda kemudian menyatakan bahwa kepala pasukan tersebut menjadi orang Kristen. ${ }^{34}$

Namun di sisi lain, hal yang sangat ironis terjadi kepada orang-orang Israel itu sendiri. Mereka yang adalah umat Allah dan yang telah melihat mujizat Tuhan Yesus membunuh-Nya di atas kayu salib oleh karena kebebalan dan ketidakpercayaan mereka. Dan terlebih lagi, ketika kepala pasukan dan prajurit-prajuritnya menjadi percaya ketika melihat peristiwaperistiwa yang terjadi pada saat kematian-Nya, pemimpin Israel tidak percaya dan bahkan setelah metelah mendengar berita kebangkitan-Nya mereka tetap berespon secara negatif dengan menyebar dusta (Mat 28:1115). Oleh karena itu, dalam bagian ini Matius mengkontraskan antara kepala pasukan dan para prajuritnya dengan kebebalan orang Israel yang justru

34 Hendriksen, Exposition of the Gospel According to Matthew, 976. 
semakin membuka kebobrokan orang-orang Israel. ${ }^{35}$

Melalui pembahasan eksegesis di dalam perikop ini, kita dapat menggarisbawahi beberapa hal yang sangat penting di dalam pembahasan kita untuk menyatakan keliteralan semua peristiwa yang terjadi pada saat Tuhan Yesus mati di atas kayu salib. Pertama, penekanan penulisan menggunakan bentuk aorist pasif indikatif yang menyatakan bahwa semua kejadian tersebut adalah karya Allah sendiri dan secara khusus kebangkitan dari orang-orang kudus bersifat kekal karena kebangkitan tersebut terjadi diantara Tuhan dengan orang-orang yang Ia bangkitkan. Kedua, kebangkitan orang-orang kudus terjadi sebelum Tuhan Yesus bangkit. Hal ini dibuktikan dengan analisis tekstual, dimana frase "sesudah kebangkitan Tuhan Yesus" adalah benar-benar tulisan Matius dan bukannya tambahan redaksional. Ketiga, kebangkitan sulung Tuhan Yesus dari antara orang mati yang dinyatakan di dalam surat I Korintus 15:20, membandingkan kebangkitan Tuhan Yesus dengan kebangkitan orang-orang kudus ketika Tuhan Yesus datang yang kedua kali.

\section{Kesimpulan}

Setelah pembahasan singkat yang telah kita lalui di dalam makalah ini maka kita dapat mengambil kesimpulan dengan tidak dapat terbantahkan bahwa perikop di dalam Matius 27:51-54 benar-benar terjadi secara literal meskipun memang bagian tersebut merupakan bagian yang paling janggal di dalam Alkitab. Dan kebangkitan tersebut bersifat kekal yang mana orangorang kudus yang telah bangkit tidak dapat mati kembali, meskipun masih

\footnotetext{
35 Luz dan Koester, Matthew 21-28, 563.
} 
terdapat sedikit perbedaan pandangan antara John Calvin dengan Craig L. Blomberg terkait waktu persis kebangkitan dari orang-orang kudus tersebut. Namun, setelah melakukan analisis teknik penulisan dan beberapa argumentasi lain di dalam bagian ini, kita dapat menyimpulkan dari sudut pandang Injil Matius bahwa memang dinyatakan secara sangat jelas kebangkitan orang-orang kudus terjadi pada saat kematian Kristus. Hal ini memberikan sudut pandang baru akan kuasa kematian Kristus yang menghidupkan, seperti halnya judul buku dari John Owen "kematian Kristus yang mematikan kematian". Kesimpulan yang diambil oleh John Calvin juga dapat dimengerti oleh karena di dalam konteks jamannya memiliki pergumulan untuk mensinkronisasikan bagian-bagian di dalam Alkitab, meski hal ini dapat berisiko mengaburkan penekanan yang ingin dinyatakan oleh penulis. Oleh sebab itu pendekatan harmonisasi tidak dapat terelakkan seperti tulisannya terhadap ketiga Injil Sinoptik "Harmony of Matthew, Mark and Luke".

Semua kejadian mulai dari terkoyaknya tirai Bait Allah hingga kepada penampakan orang-orang kudus di kota Yerusalem menyatakan signifikansi yang besar atas kuasa kematian Tuhan Yesus Kristus dan sekaligus menjadi bentuk pembelaan atas tindakan kebenaran yang dilakukan Kristus oleh Bapa. Selain itu, semua kejadian tersebut bukanlah muncul tiba-tiba tanpa pengaruh dari pengharapan Yudaisme seperti apa yang dikatakan oleh Tom Wright, karena kita dapat melihat Perjanjian Lama menggambarkan pengharapan akan kebangkitan orang-orang mati ketika Mesias datang, selain itu, apa yang terjadi di dalam perikop ini sedang menggambarkan murka Allah dan mencapai kulminasinya atas terkoyaknya tirai Bait Allah 
dari atas sampai bawah. Hal ini menunjukan penghukuman atas Bait Allah yang tidak dapat terelakkan sesuai dengan nubuatan Tuhan Yesus dan tanda berakhirnya ibadah persembahan korban, karena korban yang sejati yaitu Kristus telah genap. Perjanjian Lama juga menyatakan ketika Allah menarik diri-Nya dari Bait Allah maka Bait Allah akan segera hancur, dan hal tersebut terbukti ketika Bait Allah dihancurkan pada tahun $70 \mathrm{M}$.

Bagian tersulit untuk dapat dimengerti tentu saja kebangkitan orangorang kudus pada saat kematian Tuhan Yesus yang kemudian menampakkan diri di kota kudus, tetapi seperti yang telah kita bahas bahwa pemikiran ini memiliki latar belakang Perjanjian Lama yang kuat. Sehingga semua bentuk pemikiran dan arguentasi yang dipaparkan oleh Rudolf Schnackenburg dan John Dominic Crossan yang mengatakan bahwa Matius dipengaruhi oleh ide Helenistik haruslah kita tolak. Demikian juga halnya dengan pemikiran yang mengatakan bahwa bagian ini merupakan suatu pernyataan metafora atau puisi yang sedang ingin mengatakan bahwa peristiwa-peristiwa pada saat kematian Tuhan Yesus, bahkan kematian dan kebangkitan Tuhan Yesus sendiri sebagai hal yang bukan literal, haruslah kita tolak.

Di dalam semua kejadian ini, kita justru dapat melihat dengan jelas kuasa dari pada kematian Tuhan Yesus di atas kayu salib.Pertama, merupakan kematian yang membawa perdamaian bukan hanya kepada Tuhan melainkan juga kepada sesama manusia. Kedua, kematian yang memberikan konfirmasi paradoks penghakiman yang akan diterima bagi orang yang tidak percaya dan pengharapan bagi orang-orang percaya. Khususnya, bagi orang-orang percaya kematian Kristus merupakan 
kematian yang mematikan kematian itu sendiri, kematian yang bahkan memberikan kehidupan kepada para orang-orang kudus. Ketiga, kematian Kristus bahkan menjadi sebuah kematian yang bukan hanya menghadirkan kebangkitan pada orang-orang kudus tetapi juga kebangkitan spiritual yang akhirnya dialami oleh kepala pasukan dan prajurit-prajuritnya. Terakhir, bagian ini memberikan pengharapan eskatologi bagi orang-orang kudus untuk juga dibangkitkan pada saat kedatangan Kristus yang kedua. Jika kematian-Nya saja sudah digambarkan dengan begitu berkuasa, apalagi kebangkitan dan kedatangan-Nya yang kedua kali. Hal inilah yang akan memberikan pengharapan yang sangat kuat kepada pembaca dari kitab Matius untuk dapat terus memiliki iman yang sejati di dalam setiap tantangan dan pergumulan yang mereka hadapi. 